\title{
The International Workshop on Environmental Changes and Sustainable Development in Arid and Semi-arid Regions
}

\author{
Alashan Left Banner, Inner Mongolia, China \\ 10-14 September, 2007
}

\begin{abstract}
Arid regions, dominated by deserts, are characterized by a severe shortage of moisture, and a lack of perennial and integrated systems of drainage. Distributed over a very large range of temperatures, from the very hot to the very cold zones, arid regions cover about one third of the world's land surface and occur in every continent, including Antarctica. Although their environmental conditions generally represent the ultimate natural challenges for life, arid and semiarid regions are the cradles of human civilizations, as ancient Egypt, ancient Babylon, India and northern China are all in arid and semi-arid regions. Currently around $500 \mathrm{mil}-$ lion people live in deserts and desert margins, amounting to eight percent of the global population. Therefore research on arid and semiarid regions is of great importance in both the natural and the social sciences. To exchange the latest knowledge and to foster future collaborative initiatives, "The International Workshop on Environmental Changes and Sustainable Development in Arid and Semi-arid Regions" was held in Alashan Left Banner, Inner Mongolia, China in September 10-14, 2007.
\end{abstract}

This workshop was co-sponsored by the International Geographical Union's Commission on Land Degradation and Desertification (COMLAND), International Association of Geomorphologists (IAG), National Natural Science Foundation of China, Chinese Academy of Sciences, Chinese Quaternary Association (CHIQUA), Geographical Society of China, PAGES (Past Global Changes), and IGCP500 (International Geological Correlation Program 500-Dryland Change: Past, Present and Future). The local organizer was the Institute of Geology and Geophysics, Chinese Academy of Sciences, supported by the Government of Alashan District, Inner Mongolia and the Government of Alashan Right Banner. The workshop was attended by 83 delegates from 17 countries, namely Australia, Egypt, Germany, Iceland, Italy, Kuwait, The Netherlands, Oman, Poland, Slovenia, South Africa, South Korea, Spain, Sweden, the United Kingdom, the USA and China.

The workshop was focused on four themes: 1) case studies and theories relating to land degradation and sustainable development in arid and semi-arid as well as sub- humid regions of various continents; 2) comparisons of regional-scale reconstruction of Late Quaternary changes in the deserts of various climate zones (monsoon regions, subtropics and westerlies); 3) natural and human impacts on the landscape in various climate zones; and 4) interactions amongst aeolian, fluvial and lacustrine processes in desert margins.

Academician Jiaqi Liu, the President of the CHIQUA and the chairman of the organizing committee of this workshop, made the opening speech. Dr. Dayong Li, Assistant Governor of Alashan District, Inner Mongolia, delivered the welcoming address. Professor Andrew Goudie, President of IAG, and Professor Gudrun Gisladottir, Chair of COMLAND, addressed the workshop. The keynote talks were given by the following scientists: 1) Professor Arthur Conacher (University of Western Australia): A future for research in land degradation; 2) Professor Bojie Fu (Research Center for Eco-environmental Sciences, Chinese Academy of Sciences): Land degradation and rehabilitation in China; 3) Professor Andrew Goudie (Oxford University, UK): Desert dust: sources and trends; 4) Academician Ying Wang (Nanjing University, China): Discussions on the origins of the sands in the Chinese deserts; and 5) Professor Jianguo (Jingle) WU (Arizona State University, USA): A framework for sustainable development in arid and semiarid regions: with particular reference to the Inner Mongolia grassland.

Contributed papers, 55 in total, were presented in both oral and poster presentations, resulting in a very busy schedule. The contributed papers were based on original and innovative research carried out in all continents by the delegates in recent years. Both the oral and poster presentations were of very high quality, reflecting the most recent progress the scientific communities have made towards better understanding and more successful management of aridand semiarid environments. A half-day mid-conference trip offered a good opportunity for delegates to see field evidence of environmental changes in the Helan Mountains and in the Tengger desert, both located relatively close to the workshop venue in Alashan Left Banner, where the landscape is dominated by extensive sand seas, steppes and mountains.

The workshop was warmly appreciated by the people and the Government of Alashan District, Inner Mongolia, demonstrating the great importance of geoscientific work to society. The local appreciation was distinctly demonstrated not only by the welcoming address at the opening ceremony, but also by local residents' friendly attitude that the delegates gladly experienced throughout the workshop as well as by outstanding banquets provided by the government of the district during the workshop and by the government of the Right Banner during the postconference field trip. Both banquets were greatly enriched by superb Mongolian singing and dancing, and the many informative discussions concerning society's potential adaptations to global climate changes.

The workshop was accompanied by two (pre- and post-conference) optional and fully attended field trips, into the fields of re-activated and active dunes in Inner Mongolia, respectively. The pre-conference field trip, from September 7 to September 9, dealt with the reactivation of the stable dunes and rehabilitation measures (mainly by vegetation) in the Hunshandake Sandy Land (Yang et al., 2007), located in the eastern part of Inner Mongolia. The post-conference field trip, September 14-17, offered the opportunity for participants to see the high sand dunes (often ca $300 \mathrm{~m}$ ) and permanent lakes in the inter-dune basins, as well as palaeo-shorelines indicating late Quaternary climatic changes in the Badain Jaran Desert of western Inner Mongolia (Yang et al., 2003). Both trips proved to be valuable additions to the workshop, and some delegates commented that the workshop and the field trips were "exciting, fun and intellectually stimulating". The opportunity to see the vast, complex landscapes being researched by Chinese scientists was particularly appreciated by their international colleagues, as were the meetings with some local farmers. An enhanced

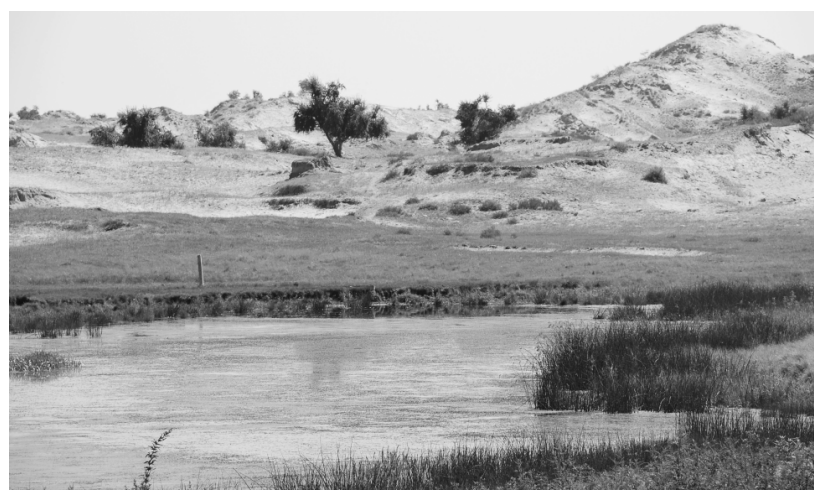

Anthropogenic induced reactivation of formerly stable dunes in the Hunshandake Sandy Land, eastern Inner Mongolia. 


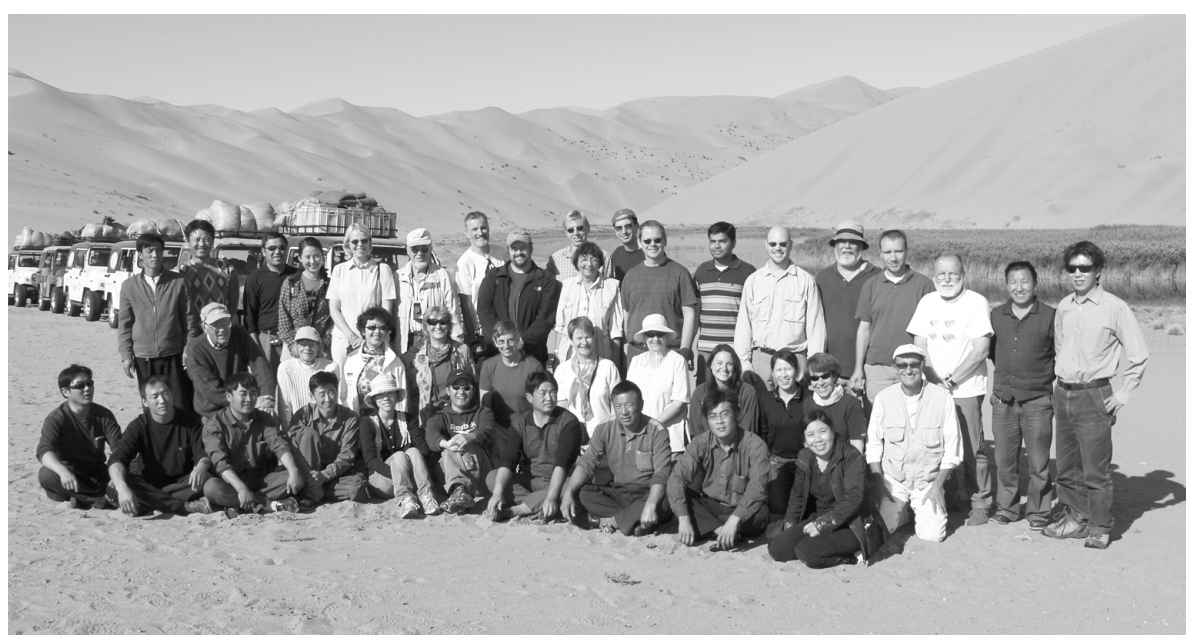

Group photo on post-conference field trip.

appreciation was also obtained of the long and complex history of this part of the world.

At the closing ceremony, Jiaqi Liu thanked all delegates for their great contributions, the Government of Alashan District, and the venue of the workshop (Longxin Hotel) for their much-appreciated support. Andrew Goudie, on behalf of the IAG, praised highly the work of the local organizers, and the presentations by delegates, in particular by the younger ones; and extended warm thanks to the funding agencies for their support. Xiaoping Yang, secretary general of the organizing committee, received the COMLAND Award from the Commission's Chair, Professor Gudrun Gisladottir.

Arrangements have been made to publish the scientific outcomes of this workshop in special issues of two internationally wellknown journals. The authors were required to revise their papers in the light of the comments and advice received at the meeting. Currently, papers on land degradation and desertification are being considered for a special issue of Geographical Research (the March issue of 2009, vol. 47 no. 1), and man- uscripts on geomorphology and palaeoenvironmental changes are being handled for intended publication in Quaternary Research.

\section{References \\ Yang X., Liu T., and Xiao H., 2003. Evolution of megadunes and lakes in the Badain Jaran Desert, Inner Mongolia, China during the last 31000 years. Quaternary International 104, 99-112. \\ Yang X., Ding Z., Fan X., Zhou Z., and Ma N., 2007. Processes and mechanisms of desertification in northern China during the last 30 years, with a special reference to the Hunshandake Sandy Land, eastern Inner Mongolia. Catena 71, 2-12.}

\section{Xiaoping Yang}

Institute of Geology and Geophysics

Chinese Academy of Sciences

Beijing

CHINA

xpyang@mail.igcas.ac.cn

\section{Arthur Conacher}

School of Earth and Geographical Sciences

University of Western Australia

AUSTRALIA

Arthur.Conacher@uwa.edu.au

The presentations, given at the Conference may be grouped into following main topics:

- Neotectonics, geodynamics and paleogeography of coastal zones (Bitinas, A., Damušyte, A., Dobracki, R., Jegliński, W., Koszka-Maroń, Raukas, A., Relisko-Ryba, J., Miotk Szpiganowicz, G., Uścinowicz, S., Uścinowicz, G., Zachowicz, J.);

The conference "Glaciotectonic structures, palaeobasins and neotectonic setting" (August 27-31, 2007, Lithuania), organized by the Lithuanian Geological Survey and the Polish Geological Institute was held under the auspices of the European Union Project MELA (Morphotectonic map of the European Lowland Area), Contract No. MTKD-CT-2004-003108, http://www. mela.3dsign.pl). The event was the 2 nd Conference of the MELA project.

The MELA conference was focused on discussion of the relationship of glaciotectonic structures, Quaternary palaeobasins and neotectonic setting, the geological modeling and visualization, digital mapping of subsurface relief and remote sensing. However the methodology of creation of the Morphotectonic Map of the European Lowland Area was the main subject of the Conference.

The territory of Lithuania can be regarded as one of classical regions having a Quaternary cover formed during continental glaciations. The average thickness of cover is $130 \mathrm{~m}$ and varies from $10-30 \mathrm{~m}$ in the northern part of Lithuania - the area of prevailing glacial erosion - up to 200-300 meters in marginal highlands and the buried valleys of palaeoincisions. Through the Quaternary Period Lithuania was covered by continental ice sheets that originated in Fennoscandinavia and which correspond to all glaciations known so far in Eastern Europe, thus producing a very complicated structure for the Quaternary in Lithuania.

The relationship of Quaternary structure with morphotectonic phenomena was demonstrated and discussed during the conference and field excursions and the knowledge gained meshed with the scientific focus of the Conference.

The Conference was attended by 49 geoscientists from Denmark, Estonia, Germany, Lithuania, The Netherlands and Poland.

During the conference 20 oral presentations, poster session, workshops in three thematic groups and 1.5 day field excursion were scheduled and arranged.
- Glaciotectonics (Aleksa, P., Bitinas, A., Piotrowski, A.);

- Satellite interferometry and geophysics (Graniczny, M., Cyžiene, J., Korabliova, L., Mikulenas, V., Minkevičius, V., Satkūnas, J., Wasowski, J.);

- 3D modelling of the subsurface (Dominik ,W., Juschus, O., Mazurowski, M., Schroeder, J. H.);

- Seismicity and geohazards (Pačesa, A., Lazauskiene, J., Graniczny, M. Piątkowska, A., Kowalski, Z., Satkunas. J., C̆yžienè, J., Kanopienè,R.);

- Hydrogeology of Saltdomes (Holzbecher, E., Mazurowski, M., Kohfahl, C., Bącik, A., Dobies M.);

- Geomorphology and morphotectonic studies (Piotrowski, A. Graniczny, M. Satkūnas, J., Schroeder, J. H., Bregman, E., Bosch, A., Koomen, A. J. M.);

- Public education, geoparks (Schroeder, J. H.); 


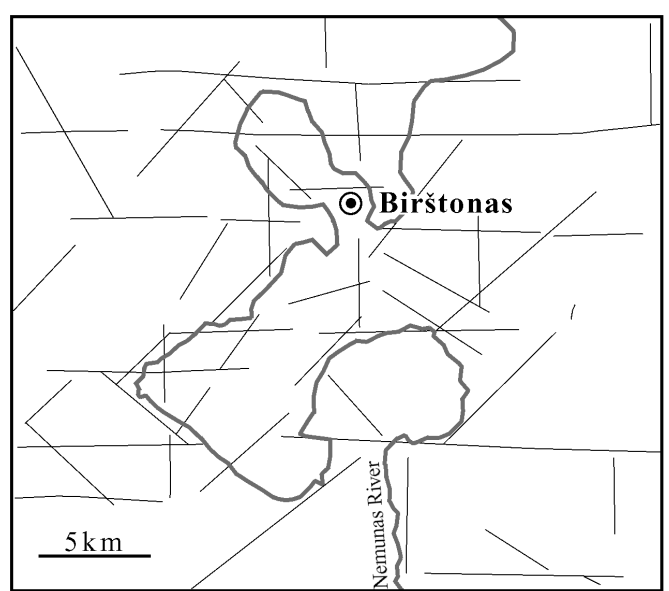

The Great Nemunas Loops and faults of the crystalline basement of the Birstonas mineral water resort area (faults defined by magnetic and gravity lineaments (after Baltrunas et al., 2005).

- Lithospheric archeology (Sliaupa, S., Ershov, A.);

- Recent vertical movements (Zakarevičius A., S̆liaupa, S., Anikenienè, A., Dėnas, Z̆).

During the field trips (led by Bitinas A., Cyziene J., Satkunas J. and Sliaupa S.) a number of geological sites with different aspects of morphotectectonic implications were visited and discussed. Among them the Puckoriai outcrop in Vilnius (63 m high, glaciotectonic phenomena of Saalian age), Devil's hole (over $40 \mathrm{~m}$ deep thermorkarstic depression, resembling meteoritic crater, located in the relief of the Weicheselian marginal relief), Rokai outcrop in the vicinity of Kaunas (34 m high section with Middle Weichselian lacustrine and Upper Weichselian glacial complex, manifestating active geodynamic phenomena, probably correlating with an active neotectonic zone), Birštonas saline mineral water springs (neotectonically faulted zone, Cambrian, Triassic, Cretaceous and Quaternary aquifers) and other sites of historical and landscape values (Medieval Punia mound, Kernave historical and archaeological reserve, Trakai Medieval Castle).

Probably the best example of morphotectonic phenomena that was demonstrated and discussed during the field trip was the area of the Great Nemunas Loops, in the central part of which the Birs̆tonas resort was established in 1846, due to occurrences of saline mineral waters.

The Nemunas River, one of the largest rivers of the Baltic region, is characterized by a generally straight valley. In the middle part of its course the Great Nemunas Loops are distinct features that occupy an area of $320 \mathrm{~km}^{2}$ near the Birstonas Resort. The Nemunas valley here is $1.5-5 \mathrm{~km}$ wide and $45-80$ $\mathrm{m}$ deep. The loops are cut into a glaciolacustrine plain confined between glacial and deltaic relief complexes and were formed during the two last phases of glaciations. The origin of the entrenched loops, as large as $6-10 \mathrm{~km}$, can not be explained in conventional terms of river meandering. The activity of the underlying tectonic structures is the major factor, with the Great Nemunas Loops being confined to the Birstonas tectonic depression. Despite their small magnitude, the neotectonic structures within the depression significantly influenced the glacial and melt-water sedimentation (and hence the topography) that controlled the geometry of the Nemunas Valley. The initial sinuosity of the valley has only been slightly enhanced by later lateral erosion. Fault activity is indicated by numerous mineral water springs and straight channel segments. Only a few sites of similar mineral water discharge are documented in Lithuania, suggesting the specific neotectonic setting of the Great Nemunas Loops. Inspection of drill cores has revealed the inheritance of the Nemunas valley from underlying palaeovalleys of the Eemian and Holsteinian Interglacials, implying a persistence of the controlling factors.

Extensive data on geology, tectonics, geomorphology and palaeogeography of the Great Nemunas Loops were collected during detailed geological and geophysical mapping carried out in the early 1970s. Numerous fresh and mineral-water supply boreholes have provided information on the Quaternary and sub-Quaternary geology. The stratigraphy and tectonic fabric of the sedimentary succession was reconstructed from one deep $(800 \mathrm{~m})$ well drilled to the crystalline basement, fifteen geological mapping wells

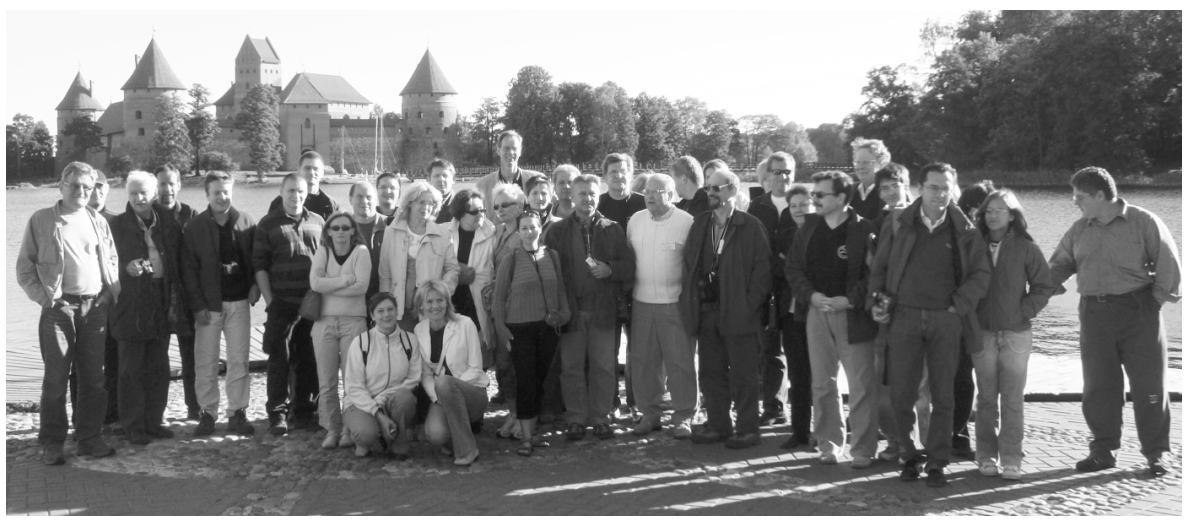

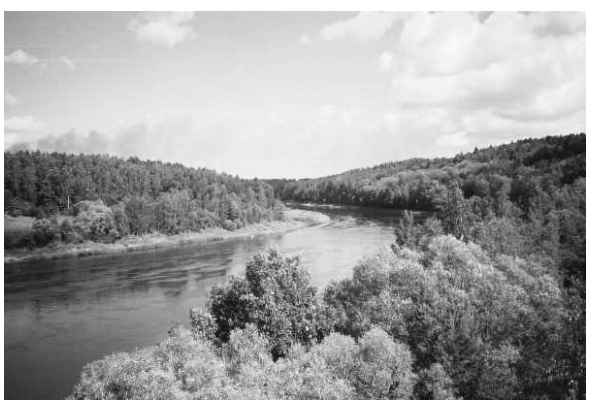

The Great Nemunas Loops and faults of the crystalline basement of the Birstonas mineral water resort area (faults defined by magnetic and gravity lineaments (after Baltrunas et al., 2005).

200-400 m deep (down to the Permian and Silurian), and several hundred hydrogeological wells.

The main output of the MELA project (www.mela.3dsign.pl/) will be presented at the symposium 'Morphotectonics of lowland areas' during the 33rd IGC in Oslo, August 2008. This symposium will deal with the problems arising from the activities of subsurface structures in connection with active subsurface and surface processes, the impact of tectonic structures on glacial morphology and glacial processes, techniques and methodologies of morphotectonic investigations, and mapping and modelling.

The proceedings of the 2nd MELA Conference Glaciotectonic structures, palaeobasins and neotectonic setting, August 27-31, 2007, Vilnius, Lithuania: Volume of Abstracts, Excursion Guide compiled by Satkūnas, J., Čyžienè, J., and Bitinas, A (Lithuanian Geological Survey, Polish Geological Instituten-Vilnius: LGT, 2007. $69 \mathrm{pp}$.) are available at the $w w w . l g t . l t$.

\section{Jonas Satkūnas}

Lithuanian Geological Survey (corresponding author)

LITHUANIA

jonas.satkunas@lgt.lt

\section{Marek Graniczny}

Polish Geological Institute

POLAND

\section{Andrzej Piotrowski}

Polish Geological Institute POLAND

Participants of 2nd MELA conference near Trakai castle. 


\title{
The XVI International Congress on the Carboniferous and Permian (ICCP 2007)
}

\author{
Nanjing, China, June 21-24, 2007
}

The XVI International Congress on the Carboniferous and Permian (ICCP2007), was successfully held at the Dongjiao State Guesthouse in Nanjing, China, from 21 June to 24 June, 2007. It was organized by the Nanjing Institute of Geology and Palaeontology (NIGP), the State Key Laboratory of Palaeobiology and Stratigraphy (LPS), the Institute of Geology of the Chinese Academy of Geological Sciences, China University of Geosciences, and Nanjing University, and was generously sponsored by the Chinese Academy of Sciences (CAS), the National Natural Science Foundation of China (NSFC), the Ministry of Science and Technology of China (MST), the International Subcommission on Carboniferous Stratigraphy (SCCS), and the International Subcommission on Permian Stratigraphy (SPS). The congress was successful with one hundred forty-three participants coming from twentynine different countries.

Activities at the congress included four days of indoor oral and poster presentations, two pre-congress field excursions, and three post-congress excursions. The opening and closing ceremonies were chaired by Xiangdong Wang and Shuzhong Shen. The congress was also honored by the presence of $\mathrm{Dr}$ James Ogg (International Commission on Stratigraphy), Drs Yucheng Chai and $\mathrm{Yu}$ Liu (Natural Science Foundation of China), and Drs Shaoping Zhou and Shijie Li (Chinese Academy of Sciences). After a welcoming address by Dr Qun Yang, deputydirector of the Nanjing Institute of Geology and Palaeontology, Drs Yucheng Chai (NSFC), James Ogg (ICS), Henk Pagnier (Chairman of last ICCP in Utrecht, Netherland), Charles Henderson (SPS Chair) and Xiangdong Wang (Co-chair of ICCP2007) gave important congratulatory and opening addresses. The closing ceremony was addressed by Drs Philip Heckel (SCCS chair) and Shuzhong Shen (Co-chair of ICCP2007; SPS Secretary).

Following the opening ceremony on the first day of the congress, nine plenary talks were presented on Earthtime (Samuel Bowring), P-T extinction (Hongfu Yin), C-P pteridosperms (Hans Kerp), C-P glaciation and aridification based on oxygen isotopic records (Ethan Grossman), Pennsylvanian glacial-eustatic cyclothems (Philip Heckel), the impact of icehouse on tropical vegetation and plant evolution (Hermann Pfefferkorn), Lopingian correlation and GSSPs (Charles Henderson), P-T rapid deforestation in South China (Shuzhong Shen), and Early Triassic biotic recovery strategies (Douglas Erwin).
During the four-day congress, our colleagues intensively discussed various aspects of stratigraphy, palaeontology, sedimentology, and palaeoclimatology. It is noteworthy that many critical issues of broad interest were discussed during this congress. A total of one hundred and sixty-nine papers was presented in the following twelve different sessions, which highlight the multidisciplinary character of the congress:

1) Late Palaeozoic floras as proxies for climatic change. Chaired by Hermann Pfefferkorn and Jun Wang.

2) Carboniferous and Permian macro- and microfossils; integrative stratigraphy and high resolution biostratigraphy. Chaired by Ian Somerville, John Groves and Lucia Angiolini.

3) Stratotypes, boundaries and global correlations. Chaired by Barry Richards and Charles Henderson.

4) Carboniferous and Permian reefs, biofacies, and basin analysis. Chaired by Markus Aretz.

5) Evolutionary palaeogeography and palaeoclimatology, Pangea formation and breakup. Chaired by Richard Lane and Walter Snyder.

6) Isotopic geochemistry and geobiology in the Permo-Carboniferous. Chaired by Ethan Grossman and Horng-sheng Mii.

7) Gondwana and peri-Gondwana faunas, stratigraphy, and geology (In cooperation with IGCP516: Geological anatomy of East and South Asia). Chaired by Xiaochi Jin and Katsumi Ueno.

8) Bio-diversity patterns and quantitative analysis of biotic databases; computerized palaeontology. Chaired by Yue Wang.

9) End-Permian biotic mass extinction and early Triassic recovery. Chaired by Douglas Erwin and Shuzhong Shen.

10) Cyclothems and sequence stratigraphy. Chaired by Philip Heckel.

11) Carboniferous-Permian non-marinemarine correlations. Chaired by Joerg Schneider.

12) Earthtime-Carboniferous and Permian geochronology. Chaired by Samuel Bowring.

Dr Vladimir Davydov (Vice-chair of SPS) gave a short course on PaleoStrata, and Drs Walter Snyder and Richard Lane organized a meeting on Geosystem. In addition, two sessions in honour of two distinguished Chinese palaeontologists, were held. One was to celebrate the 90th birthday of Prof. Xingxue $\mathrm{Li}$, who has made great contributions to palaeobotany in China, and the other was in memory of the late Professor Yugan
Jin who was the main organizer of the XIth International Congress on the Carboniferous and Permian held in Beijing twenty years ago and who made significant contributions to Permian stratigraphy and the end-Permian mass extinction.

Five field trips were offered before and after the congress. These trips were designed to show participants some of the most important Carboniferous and Permian sequences in China, and all of them were heavily booked. The pre-congress excursions were "GSSPs of the Permian-Triassic boundary and the base-Changhsingian at the Meishan section" (led by Shuzhong Shen, Charles Henderson and Changqun Cao) and "Pennsylvanian to Lower Triassic continental sequences in Hebei and Inner Mongolia" (led by Jun Wang and Lujun Liu). Three post-congress excursions were "Peri-Gondwanan Carboniferous to Permian sequences in West Yunnan" (led by Xiangdong Wang, Tetsuo Sugiyama and Changqun Cao), "Stratigraphy and lithofacies of the Tournaisian and Visean in the Guilin-Liuzhou area, Guangxi, South China" (led by Xiaochi Jin, Francois Devuyst, Luc Hance, Edouard Poty, Baoan Yin, Xianghu $\mathrm{Wu}$, and Hongfei Hou) and "Pennsylvanian and Lower Permian carbonate succession from shallow marine to slope in southern Guizhou" (led by Yue Wang, Katsumi Ueno, and Yuping Qi).

The abstract volume was printed before the congress as a supplementary issue of the Journal of Stratigraphy (Wang et al., eds., 2007) and included 185 abstracts. In addition, a special issue of Palaeoworld in memory of late Professor Yugan Jin was published shortly after the congress. All the papers are already available on the Elsevier Science Direct (http://www.sciencedirect.com/science/journal/1871174X). This special issue includes a memorial paper and seventeen scientific papers exploring a number of research areas that are either directly or indirectly related to Professor Jin's research interests. Thus, they obviously reflect his profound influence in the field (Shen et al., eds, 2007).

The Proceedings of the congress will be published in two different journals Geological Journal and Palaeoworld, both peerreviewed international journals. The Organizing Committee of ICCP 2007 hopes that all the participants will submit papers to the

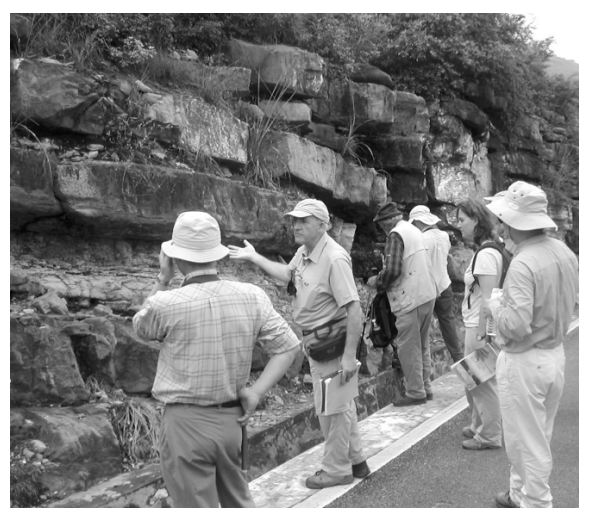

Field trip after the congress. 
Proceedings. We shall put these papers into publication as soon as possible, with several volumes to come out before the opening of the next congress.

The ICCP 2007 in Nanjing represented a significant contribution to the understanding of the amazing geological record of Carboniferous and Permian biotic and physical processes. It also provided an excellent method for demonstrating the latest research achievements in the field of Carboniferous and Permian sedimentology, and promoted international exchange and cooperation in geological sciences. During the congress, the international Permanent Committee of the ICCP held a business meeting where several important decisions were adopted. The committee also decided that the next congress would be held in Perth, Australia, a country where the Gondwanan Carboniferous and Permian strata are well-preserved.

\begin{tabular}{l}
\hline References \\
Wang Yue, Zhang Hua, and Wang Xiaojuan (eds), \\
2007, XVI International Congress on the Car- \\
boniferous and Permian, Abstracts. Journal of \\
Stratigraphy, vol. 31, suppplement 1, 242 p. \\
Shen Shuzhong, Wang Xiangdong, and Erwin, D. \\
H. (eds), 2007, Contributions to Permian and \\
Carboniferous Stratigraphy, Brachiopod
\end{tabular}

Palaeontology and End-Permian Mass Extinctions: In Memory of Professor Yugan Jin. Palaeoworld, vol. 16, no. 1-3. 263p.

Xiangdong Wang, Shuzhong Shen, and Yue Wang

State Key Laboratory of Palaeobiology and Stratigraphy

Nanjing Institute of Geology and Palaeontology Chinese Academy of Sciences

Nanjing 210008

CHINA

xdwang@nigpas.ac.cn

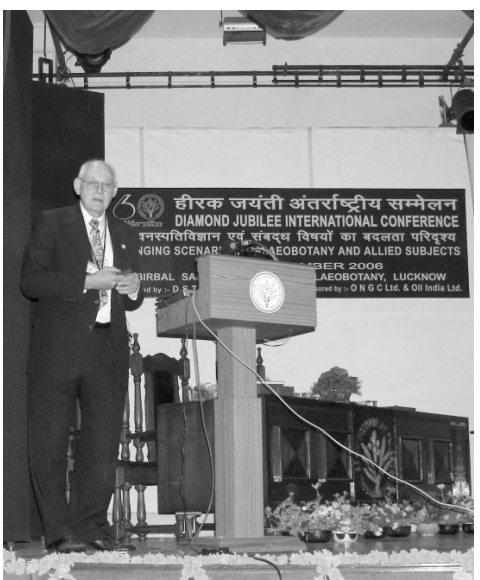

Prof. David Dilcher gave a plenary lecture.

greenhouse climate and understanding the Earth System process. B.S. Venkatachala, former BSIP Director, presented a Diamond Jubilee Lecture entitled "Economic Palynology: Industrial Applications". He emphasized that palynology has developed as a multifaceted discipline with new applications over a wide spectrum of geological areas, serving as an aid to resolving stratigraphic and palaeoenvironmental problems. Recent applications of palynofossil groups include: the dating of sediments integrated with seismic and electrolog data; the highresolution bio-stratigraphy for finer zonations; correlation of terrestrial and marine sediments; palaeoenvironment and palaeoclimate reconstructions; and sequence biostratigraphy. J. William Schopf from the University of California presented a plenary lecture on "Three-dimensional Morphological and Chemical Imagery of Permineralized Plants and Precambrian Microorganisms". He emphasized that application in tandem of confocal laser scanning microscopy and Raman imagery can provide new information about the morphology, cellular anatomy, taphonomy, and geochemical maturity of kerogenous permineralized fossils. These techniques hold promise for fruitful palaeobotanical investigation both of chert- and coal ball-permineralized fossil floras. David L. Dilcher from the University 


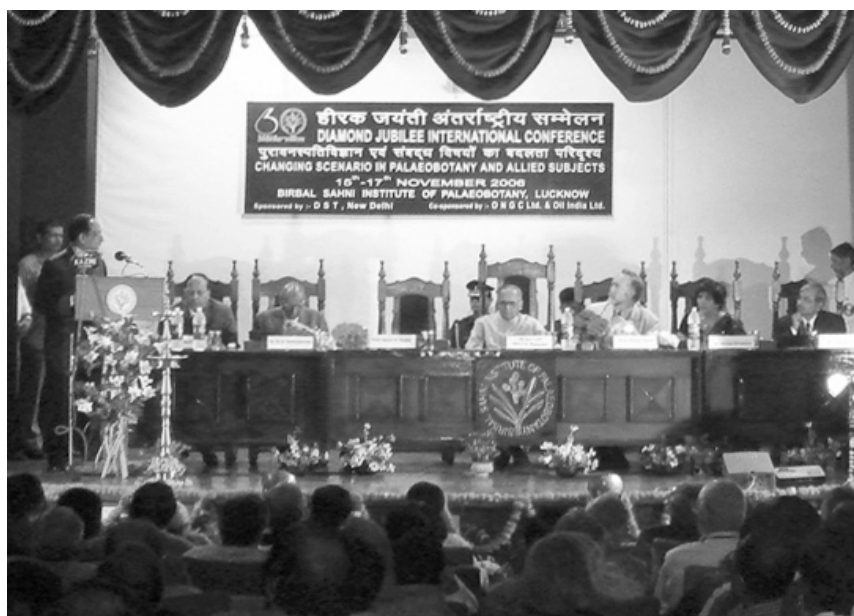

The opening ceremony of the conference.

of Florida presented a lecture on the "Fossil Record of Angiosperm Evolution". $\mathrm{He}$ pointed out that molecular systematic data can be used in concert with the fossil angiosperm data. The ancestry of the angiosperms and the ancestral group that gave rise to them can only be understood from the fossil record. When we can establish a fossil record that tracks the reproductive morphology of ancestral angiosperms we can assess the early character evolutions in time for the earliest historical record of flowers. Cheng-Sen Li from the Institute of Botany, Chinese Academy of Sciences, was invited to give a plenary lecture on "Cenozoic Vegetation and Environment in Southwest China". The Neogene vegetation, climate and uplift of the mountains in West Yunnan of China were presented. A comparison between the Tertiary floras of Southwest China and Northeast India has provided clues for tracing the antiquity of the Himalayan flora and the history of the region's climate.

A variety of talks made up the session "Applications of Modern Tools/techniques in Palaeobotanical Research". They included: metal accumulation and hyper accumulation in plants; new micro-sieving techniques in pollen analysis; sedimentation rates of eolian sequences from the north Chinese Loess Plateau and their palaeoclimatic significance; magnetic minerals and their responses to climate change; and geochemical approaches as a contemporary trend in palaeobotany.

Patterns of angiosperm origin and early evolution" were one of the topics for sessions. Ge Sun from Jilin University of China reported recent advances in the study of early angiosperms in China. The discovery of early angiosperm Archaefructus from Western Liaoning has been given much attention by palaeobotanists and botanists worldwide. The recent recovery of genus Hyrcantha from western Liaoning has remarkable significances for the origin and early evolution of angiosperms. Other presentations in this session focused on the study of a variety of angiosperm groups in relevant regions, such as the evolution of the Cocoseae, the history of Neotropical plant diversification, the his- tory and development of angiosperms in the Himalaya flora, the evolutionary history of angiosperms in India on the basis of megafossils, and evolutionary trends in the Cretaceous-Tertiary dicotyledonous wood of India.

A series of talks was focused on the topic "Palynology and Fossil Fuel Exploration", including the Late Jurassic-Early Cretaceous palynofloral transition in the South Rewa Basin, India, high resolution palynostratigraphy of the Cretaceous and pre-Cretaceous subsurface sediments, and Palaeocene to Eocene palynostratigraphy and palaeoenvironment analysis of the Nardipur Depression area of India. In addition, the biostratigraphy and palaeoenvironmental analysis of Palaeogene sediments and the palaeoecology of Vastan lignite mine of the North Cambay Basin, India were reported.

The session "Biodiversity through Time" contained many topics concerned with fossil floras. Z. Kvacek from Charles University, Czech Republic, reported on the Tertiary vegetation of Europe and its dynamics and climatic signals based on new approaches in geobotany. The refined floristic spectra provide the palaeoclimate data on a larger scale using new objective approaches, including Co-existent, CLAMP, and plant physiology data. Additionally, some new findings on fossil coniferous and angiosperm wood, tree-ring records, fossil algae, fossil Gleicheniaceae plants, new lycopsid cones from the Upper Devonian, and fossil Isoites of the Isoetalean were reported in this session.

The session "Quaternary Palaeoclimate and Palaeobotanical Proxies" was one of the major attractions of the conference. Different proxies were presented and discussed, such as: calcretes as proxy for palaeopreciptation and palaeovegetation; the vegetation and environment during Middle-Late Palaeolithic age of Lingnan Area, China; radiocarbon analysis of a banded coral from eastern coast of Australia; migration of tree-line species in response to recent climate change in the western Himalayas, India; palaeoclimate studies based on oxygen isotopes in marine sediments and speleotherms; palynological records of mangrove degradation around Chilka Lake, Orissa, India; and multiproxy analysis of quaternary deposits from Kumaun Himalaya - an assessment of past organic matter and climate.

The "Gondwana Floristics and Biostratigraphy" session included topics such as: changing scenarios in Lower Gondwana Palaeobotany; floral diversity in the Upper Gondwana Succession (Early Cretaceous) near Amravati District, Manarashtra, India; and palaeophytogeographical implications of Early Carboniferous floras of Kashmir Himalaya.

The session on "Archaeobotany and Anthropogenetic Activities" included a wide variety of topics, such as the early wheat and rice agriculture in Northwest China; vegetation and environment during the Middle-Late Palaeolithic age of the Lingnan area, China; microscopic analysis of ca. 2500 years old cattle dung from the Yanghai Tomb at Xinjiang, China; the discovery of Asian millets and African cultigens from north Indian archaeological sites; and a review of archaeobotanical researches at Allahabad University in India.

Some of the presentations were arranged in the session"Origin and Evolution of Early Life", in which talks concentrated on the search for pre-Edicaran Metazoan fossils in China and India, and the Mesoproterozoic silicified microbiotas of Russia and India, focusing on the characteristics and contrasts. Other presentations were made regarding the biostratigraphic and evolutionary significance of Proterozoic organicwalled microfossils, Meso-Neoproterozoic stromatolites and microbiota, Proterozoic biocommunities, and the Indian Ediacaran microbiota.

Additionally, several remarkable talks were also presented on the topic of Mass Extinctions, Time Boundaries and the Fossil Record. The volcanic eruption was considered to be the potential cause of extermination of dinosaurs at K/T boundary in India, and coprolites were investigated to know the dietary requirements of dinosaurs and other ancient cattles.

During the conference, the Palaeobotanical Society of Lucknow held the award ceremony for the Palaeobotanical Society International Medal (2003 and 2005), there being two recipients, Professor David Dilcher from the University of Florida and Professor S. Chitaley from the Cleveland Museum of Natural History in Ohio.

This conference emphasized the latest developments in palaeobotany and allied subjects from a global perspective. It included the many aspects of basic and applied research in palaeobotany with various technical sessions, general lectures, plenary lectures and some special lectures delivered by experts from various parts of the world. Special arrangements were also made for the poster sessions, museum exhibitions, field excursions and Indian cultural performances.

\section{Yongdong Wang}

Nanjing Institute of Geology and Palaeontology

Chinese Academy of Sciences

39, East Beijing Road, Nanjing 210008

CHINA

ydwang@nigpas.ac.cn

\section{Neeru Prakash}

Birbal Sahni Institute of Palaeobotany 53, University Road, Lucknow 226007

INDIA

neerup_in@yahoo.com 